\title{
CLINICAL AND SOCIO-DEMOGRAPHIC CHARACTERISTICS OF PERSONS WITH TRAUMATIC PARAPLEGIA LIVING IN SÃO PAULO, BRAZIL
}

\author{
Leila Blanes', Lana Lourenço', Maria Isabel Sampaio Carmagnani', Lydia Masako Ferreira'
}

\begin{abstract}
Objective: To evaluate the clinical profile of individuals with paraplegia living in São Paulo, Brazil. Method: The sample consisted of 60 outpatients with traumatic paraplegia from whom clinical and demographic data were obtained. Results: The patients were predominately men (86.7\%), single (61.7\%), with mean age of $32.9(S D=9.47)$ years, and complete or incomplete primary education (63.3\%). Although $41.7 \%$ were born in different states, all patients were current residents of São Paulo, Brazil. The most frequent cause of paraplegia was firearm injury (63.3\%) followed by car accident $(20 \%)$. The most common complications observed in the patients were urinary ( $88.3 \%$ ) and anal $(45 \%)$ incontinence, muscle spasm (65\%), and pressure ulcers (26.7\%). Conclusion: The data revealed that the sample consisted predominantly of young males with low education level, showing complications due to $\mathrm{SCl}$, and who were victims of urban violence.
\end{abstract}

KEY WORDS: paraplegia, spinal cord, caractheristics.

\begin{abstract}
Características clínicas e sócio demográficas de pessoas com paraplegia traumática na cidade de São Paulo
Resumo - Objetivo: Avaliar o perfil de paraplégicos que vivem na cidade de São Paulo. Método: Foram incluídos 60 paraplégicos por causa traumática. $O$ instrumento de coleta de dados constava de dados demográficos e clínicos. Resultados: A maioria era do sexo masculino (86,7\%), com média de idade igual a 32,9 (DP=9,47) anos, sendo $61,7 \%$ solteiros. Em relação à naturalidade $41,7 \%$ nasceram em outros estados, porém todos residiam em São Paulo. A causa mais freqüente da paraplegia foi por ferimento por arma de fogo (63,3\%), seguida por acidente automobilístico (20\%). Quanto às complicações decorrentes da lesão medular, destaca-se a presença de incontinência urinária $(88,3 \%)$ e anal $(45 \%)$, o espasmo muscular $(65 \%)$ e a úlcera por pressão (26,7\%). Conclusão: Os resultados encontrados permitiram verificar uma amostra de pessoas em sua maioria do sexo masculino, jovem, com baixa escolaridade e que apresentam complicações decorrentes da lesão medular e em grande parte, vítimas da violência dos grandes centros urbanos.
\end{abstract}

PALAVRAS-CHAVE: paraplegia, lesão medular, características.

Spinal cord injury $(\mathrm{SCl})$ is defined as any lesion of the spinal cord that can cause neurological damage, which may affect motor, sensitive, visceral, sexual and trophic functions. $\mathrm{SCl}$ can be either traumatic or nontraumatic in origin. Traumatic SCl may be caused by car accidents, firearm injuries, shallow water diving, or falls from high places. Nontraumatic SCl may be a result of tumors, infections, vascular alterations, malformations, and degenerative or compressive processes. A precise diagnosis is essential in the definition of the prognosis and rehabilitation program to be adopted'. In the United States, the num- ber of new cases per year is estimated at 10000 , of which $65.4 \%$ are related to violence and car accidents, leading to direct costs of US\$ 7,736 billion/year².

The individual reaction to disability depends on a series of factors, especially the type, cause and severity of the disability, age at which the injury occurred, sex, psychological resources, temperament, self-esteem, availability of family support, income, available technology, and availability of government subvention. This author also pointed out that feelings of uselessness, sense of inferiority, and low self-esteem result from the impossibility of

Federal University of São Paulo, São Paulo SP, Brazil (UNIFESP): 'Division of Plastic Surgery; ${ }^{2}$ Department of Nursing.

Received 28 November 2008, received in final form 23 March 2009. Accepted 13 April 2009.

Dra. Leila Blanes - Division of Plastic Surgery / UNIFESP - Rua Napoleão de Barros 715 / 49 andar - 04023-062 São Paulo SP - Brasil. E-mail: leilablanes@ ig.com.br 
performing simple tasks, the need to be guided, fed and taken to the bathroom ${ }^{3}$. In Brazil, little attention has been given to patients with chronic injuries like traumatic $\mathrm{SCl}$. Many of these patients have complications, such as pressure ulcers, which make rehabilitation more difficult. In our rehabilitation centers, the clinical evolution of $\mathrm{SCl}$ patients is probably related to social and family support.

The aim of this study was to provide information on the main characteristics of persons with traumatic paraplegia living in São Paulo, Brazil. This information may contribute to prevent $\mathrm{SCl}$ and improve the quality of life of $\mathrm{SCl}$ patients.

\section{METHOD}

This was a descriptive and transversal study. The sample consisted of $60 \mathrm{SCl}$ outpatients.

Statistical analysis was performed based on preliminary data from a pilot study with $60 \mathrm{SCl}$ subjects, which was the sample size necessary to achieve a power of $81 \%$ at a significance level of 0.05 .

Data were collected at the São Paulo Hospital (40\%), Lar Escola São Francisco Rehabilitation Center (33.3\%), Sports Association for the Disabled-ADD (20\%), and at the patients' home (6.7\%).

Eligibility criteria included patients with traumatic $\mathrm{SCl}$ who were at least 18 years of age.

Each $\mathrm{SCl}$ patient was initially contacted and informed about the purpose of the study; it was determined whether injury was traumatic and whether the patient met the inclusion criteria.

A letter containing information about the study, written in simple and clear language, was read to the participants and written informed consent was obtained from all patients. Confidentiality was assured.

Socio-demographic and clinical characteristics of the patients were assessed through a questionnaire.

Data were evaluated by descriptive analysis of the socio-demographic and clinical variables, in the form of mean and percentage values.

The correlation among numeric variables was assessed using Pearson's linear coefficient. All statistical tests were performed at a significance level of $0.05(p<0.05)$.

This study posed no risk to the participants and was approved by the Research Ethics Committee (CEP) of the Federal University of São Paulo, SP, Brazil.

\section{RESULTS}

The $\mathrm{SCl}$ patients were predominately men (86.7\%), single $(61.7 \%)$, with 32.9 mean age (SD=9.47) years. Of the 60 patients, 38 (63.3\%) had complete or incomplete primary education, 19 (31.7\%) had complete or incomplete secondary education, and $3(5 \%)$ had college education.

Thirty five (58.3\%) of the $\mathrm{SCl}$ patients were from cities in São Paulo, while 25 (41.7\%) were born in different states; however, all patients were current residents of São Paulo.
It was also observed that 38 (63.3\%) of the patients relied on Social Security as their only source of income.

The most common cause of paraplegia was firearm injury $(63.3 \%)$ followed by car accident (20\%). Work accidents and motorcycle accidents are among other causes (16.7\%) of traumatic $\mathrm{SCl}$. Levels of $\mathrm{SCl}$ ranged from $\mathrm{T} 1$ to T10 for $48(80 \%)$ of the patients, from T11 to L2 for 10 (16.7\%), and from L3 to S2 for $2(3.3 \%)$ of the patients. The most common complications were urinary and anal incontinence, muscle spasm and pressure ulcers.

\section{DISCUSSION}

Spinal cord injury is among the chronic conditions that cause disability and consume resources from the health sector. $\mathrm{SCl}$ is a condition that will last for the patient's lifetime, resulting in significant physical, psychological, social and economic consequences. It affects almost all aspects of the life of patients and family members involved in their care.

The $\mathrm{SCl}$ patients who participated in this study were predominately men $(86.7 \%)$, single $(61.7 \%)$, with mean age of 32.9 (SD=9.47) years, and had complete or incomplete primary education (63.3\%).

Traumatic $\mathrm{SCl}$ is most prominent among young men between the ages of 21 and 35 years, and is considered a relevant social problem that affects a portion of the economically active population, who are obliged to interrupt their professional activities and plans for the future, with disastrous consequences in terms of personal, family and social organization ${ }^{1,4-6}$. Among the $\mathrm{SCl}$ patients, the minimum elapsed time since injury was 6 months, and the maximum, 17 years. Thirty eight $(63.3 \%)$ of the patients were Social Security beneficiaries or homemakers with no professional activity, $11.7 \%$ were retailers, and $15 \%$ had other occupations such as actor or wheelchair basketball player. Although the sample is comprised of young adults, there are many obstacles that prevent these individuals from getting a job, forcing them to rely on Social Security benefits.

With regard to the marital status, the sample had similar characteristics to that described by De Vivo and Fine ${ }^{7}$ in a study with $\mathrm{SCl}$ patients, and in which the authors also indicated the prevalence of wives as caregivers, followed by other family members. According to De Vivo and Fine ${ }^{7}$ the divorce rate after injury is high, ranging from $8 \%$ to $48 \%$. De Vivo et al. ${ }^{8}$ evaluated 622 persons enrolled in the National Spinal Cord Injury Statistical Center (USA) data set since 1973, finding a total of 126 divorces, which compares to the 74 expected, based on the age-sex-specific annual divorce rates for the United States population.

The most frequent cause of paraplegia was firearm injury $(63.3 \%)$ followed by car accident (20\%), denoting an increase in the violence in large urban centers. 
In the present study, levels of $\mathrm{SCl}$ ranged from $\mathrm{T} 1$ to T10 for $80 \%$ of the patients. The injury affects the segments of the spinal cord. Injuries above T1 cause tetraplegia, while paraplegia results from injuries to $\mathrm{T} 1$ and below segments. Due to the mechanical characteristics of the spinal cord and spinal medulla, the low cervical region and thoracic-lumbar junction are the areas most affected by traumatic injuries?

In this study, the most common complications resulting from SCl were urinary (88.3\%) and anal (45\%) incontinence, muscle spasm (65\%) and pressure ulcers (26.7\%). All these complications can be controlled, however, in some cases, it can become a situation as bad as the restriction of movements. Urinary and anal incontinence can be embarrassing. Pressure ulcer is the worst complication caused by the decrease in sensory perception and mobility. Excess pressure over bony prominences results in tissue ischemia and consequent ulceration, with frequent relapse in $\mathrm{SCl}$ patients, leading to physical, emotional and financial discomfort ${ }^{10}$.

Pressure ulcer is considered the most common cutaneous complication in persons with $\mathrm{SCl}$, and can account for $25 \%$ of the total expenses on medical care. It is estimated that $70 \%$ of the $\mathrm{SCl}$ patients have pressure ulcers, and $7 \%$ to $8 \%$ die due to complications related to these lesions ${ }^{10}$. The development of pressure ulcers can be fast, occurring mainly in the sacral, sciatic, trochanteric and calcaneum regions ${ }^{11,12}$.

Wet episodes, unpleasant odors, constant dressing changes, frequent visits to health centers, and the cost of materials for ulcer treatment, are factors that negatively affect $\mathrm{SCl}$ patients and caregivers. Ulcer stages varied from Stage II to IV. Of the 16 patients with pressure ulcer, $50 \%$ were in Stage IV, which represents the highest physical, psychological and financial burdens ${ }^{12}$.

Despite the lack of data in the literature on $\mathrm{SCl}$ patients living in São Paulo, this study presents relevant data on relatively young patients who endure significant impairment in their quality of life.

Considering that individuals with $\mathrm{SCl}$ need wheelchairs or bath chairs, special adaptations are required at home and in public facilities with regard to the width of doorways, presence of stairs, and physical environment at home, among others. Some environmental changes have been done to accommodate people with disabilities, but reduced access to public transportation, and buildings and sidewalks without ramps for wheelchairs seem to be the issues that mostly affect individuals with $\mathrm{SCl}$.

The obtained results may lead to the elaboration of strategies to reduce the impact caused by the condition in the life and health of persons with paraplegia and, consequently, improve their quality of life.

Among these strategies, the types of assistance that are receiving increased attention in the area of health are rehabilitation centers for people with physical disabilities or chronic diseases, home care assistance, and health education. These strategies open new opportunities of rehabilitation to individuals with paraplegia, as well as the possibility of being integrated into the community.

In conclusion, persons with traumatic SCI living in São Paulo represent a young population with low education level, whose lives were disrupted by violence, such as firearm injuries and car accidents.

\section{REFERENCES}

1. Barros Filho TEP. Estudo epidemiológico de pacientes com traumatismo da coluna vertebral e déficit neurológico, internados no Instituto de Ortopedia e Traumatologia de Hospital das Clínicas da Faculdade de Medicina da USP. Rev Hosp Clin Fac Med Univ São Paulo 1990;445:123-126.

2. De Vivo MJ. Causes and costs of spinal cord injury in the United States. Spinal Cord 1997;35:809-813.

3. Azevedo GR, Santos VLCG. (Handicapped) Caregiver: the social representations of family members about the caregiving process. Rev Latino Am Enfermagem 2006;14:770-780.

4. Blanes L, Carmagnani MIS, Ferreira LM. Health-related quality of life of primary caregivers of persons with paraplegia. Spinal Cord 2007;45:399-403.

5. Putzke JD, Richards JS, Hicken BL, De Vivo MJ. Predictors of life satisfaction: a spinal cord injury cohort study. Arch Phys Med Rehabil 2002;83:555-561.

6. Chan RC. Stress and coping in spouses of persons with spinal cord injuries. Clin Rehabil 2000;14:137-144.

7. De Vivo MJ, Fine PR. Spinal cord injury: its short-term impact on marital status. Arch Phys Med Rehabil 1985;66:501-504.

8. De Vivo MJ, Hawkins LN, Richards JS, Go BK. Outcomes of post-spinal cord injury marriages. Arch Phys Med Rehabil 1995;76:130-138.

9. Mendonça ABF Netto. Traumatismos raquimedulares fechados. Arq Bras Neurocir 1986;5:1-335.

10. Byrne DW, Salzberg CA. Major risk factors for pressure ulcers in the spinal cord disabled: a literature review. Spinal Cord 1996;34:255-263.

11. Blanes L, Duarte IS, Calil JA, Ferreira LM. Clinical and epidemiologic evaluation of pressure ulcers in patients at the Hospital São Paulo. Rev Assoc Med Bras 2004;50:182-187.

12. Bergstrom N, Braden BJ, Laguzza A, Holman V. The Braden Scale for predicting pressure sore risk. Nurs Res 1987;36:205-210. 